\title{
Łukasz Medeksza
}

Uniwersytet Wrocławski

\section{Urbanologia: ku odbudowie tradycyjnego miasta europejskiego - szkic krytyczny}

\begin{abstract}
Abstrakt: Termin użyty w tytule książki wrocławskiego architekta Stanisława Losego Ku urbanologii odnosi się do postulowanego przezeń „obszaru wiedzy, który zajmuje się człowiekiem w świecie zurbanizowanym". Tym samym urbanologia nie jest jednoznaczna z urbanistyką, która — zdaniem Losego - zajmuje się ekonomią, transportem czy planowaniem przestrzeni, nie zaś ludźmi. Te rozważania prowadzą Losego do pochwały średniowiecznego modelu miasta - i jego zorientowanej bardziej na wolność i kreatywność nowożytnej kontynuacji. W tym zwłaszcza do pochwały integrującej kulturowo roli chrześcijaństwa. Ale omówienie książki Losego jest jedynie pretekstem do opisania najnowszych dziejów nurtu tradycjonalistycznego w urbanistyce i zachwytów nad średniowieczem wyrażanych przez tak różnych autorów, jak René Guénon, Piotr Kropotkin czy G.K. Chesterton. Współcześnie podobnym tropem idzie neomediewalizm, który interpretuje obecne rozproszenie Europy - kulturalne, polityczne, administracyjne - jako właśnie nową wersję średniowiecza. Jednak tradycjonalizm urbanistyczny i neomediewalizm rodzą szereg pytań, które padają w tekście - m.in. o granice czerpania inspiracji ze średniowiecza, o ekonomię neomediewalnego modelu miasta czy o relacje między pojęciem żywej tradycji w urbanistyce i architekturze a stylami historycznymi.
\end{abstract}

Słowa-klucze: tradycja, tradycjonalizm, nowe średniowiecze, neomediewalizm, nowa urbanistyka, urbanologia, modernizm

Co nam może dać powrót do średniowiecznego modelu miasta? Jakie ryzyko jest z tym związane? Czy współczesna tęsknota za tym modelem dotyczy tylko jego formy, czy także jego treści — i jakich? Czy relacje form z treściami można kształtować dowolnie, czy — przeciwnie — w ślad za osadzonymi w historii formami architektonicznymi i urbanistycznymi również sposoby życia i instytucje zwrócą się ku wzorcom z przeszłości? Jak mogłaby wyglądać aksjologia i struktura społeczna neomediewalnego miasta? Czy byłoby to jednorodne kulturowo i zhierarchizowane społecznie zamknięte getto? Czy takie miasto ma swoją optymalną, niewielką skalę? Tego typu pytania wyznaczają pole badań zainspirowane neomediewalizmem oraz urbanistycznym i architektonicznym trady- 
cjonalizmem. Do wejścia w tę tematykę zachęca lektura książki Ku urbanologii autorstwa wrocławskiego architekta Stanisława Losego ${ }^{1}$.

Tekst jest podzielony na trzy części. W pierwszej omawiam główne tezy $K u$ urbanologii. W drugiej podaję przykłady rozmaitych idealizacji tradycyjnego miasta europejskiego - zarówno jego formy, jak i treści, czasem w konfrontacji z przeciwstawnym mu modelem miasta modernistycznego. Część trzecią poświęcam nasuwającym się pytaniom i wątpliwościom dotyczącym modelu europejskiego miasta tradycyjnego.

\section{Ku urbanologii - główne tezy}

Swoją książką Stanisław Lose ${ }^{2}$ apeluje, aby traktować przestrzeń (zwłaszcza miejską) jako nierozerwalnie związaną z ludźmi, którzy ją zamieszkują i przekształcają. Stąd właśnie pojęcie urbanologii. Wprowadzając je, Lose zrywa z konwencjonalną urbanistyką. Urbanologia ma być tym „obszarem wiedzy, który zajmuje się c złowi ekiem [wyr. — Ł.M.] w świecie zurbanizowanym”. A więc inaczej niż — jego zdaniem - urbanistyka, w której „to, co ludzkie [...] jest jedynie wartością pochodną", bo liczą się względy kompozycyjne, ekonomiczne,

\footnotetext{
${ }^{1}$ Mój tekst jest oczywiście jedynie wstępną zachętą do pogłębionej refleksji nad neomediewalizmem i tradycjonalizmem. Ta tematyka pojawiła się także $\mathrm{w}$ trakcie prowadzonego przeze mnie w ramach Europejskiej Stolicy Kultury 2016 projektu „Foresight Społeczny Wrocław 2036/2056”. W podsumowującej go, pięciotomowej publikacji Strategie dla Miasta Przyszłości (red. Ł. Medeksza) dwa tomy były poświęcone właśnie temu obszarowi: tom 1 - Miasta w nowym średniowieczu (red. G. Lewicki) oraz tom 3 - Miasto piękna i charakteru (red. I. Gajny). Z kolei w tomie $4-$ Miasto madre i samodzielne (red. T. Bojęć) - można znaleźć krytyczny wobec m.in. tradycjonalizmu tekst Michała Dębka Spektakl o madrym mieście.

2 Stanisław Lose (rocznik 1946) jest architektem. Obecnie związany z Katedrą Architektury Użyteczności Publicznej i Podstaw Projektowania na Wydziale Architektury Politechniki Wrocławskiej, wcześniej m.in. kierował Zakładem Architektury Budynków Społeczno-Usługowych na tym Wydziale. Na przełomie lat 60. i 70. był ważną postacią wrocławskiej sceny psychodelicznej jako autor scenografii i inscenizacji stale współpracował z legendarnymi zespołami miejscowego rockowego undergroundu: Elar-5 i Romuald \& Roman. Jak sam pisze, inscenizował koncerty tej drugiej grupy m.in. w Hali Ludowej i Sali Kongresowej. Prowadził własny eksperymentalny zespół Pryzmat. W latach 70. związał się ze światem teatru jako projektant scenografii. Dyplom architekta uzyskał ,za projekt teatru we Wrocławiu”. W tamtej dekadzie współpracował też z Jerzym Grotowskim — jako ,architekt przestrzeni teatralnej” w Instytucie Aktora Teatru Laboratorium. W 1979 r. obronił pracę doktorską pt. Elementy przestrzeni teatralnej na przykładzie polskiego teatru współczesnego. Na przełomie lat 70. i 80. brał udział w słynnych seminariach kreatywnych, prowadzonych przez prof. Tomasza Kocowskiego, psychologa z Uniwersytetu Jagiellońskiego (warto zauważyć, że seminarzystami Kocowskiego byli także m.in. tacy, by tak rzec, wizjonerzy życia społecznego związani z Politechniką Wrocławską, jak Zbigniew Bać i Jan Waszkiewicz). Od końca lat 70. rozwija swoją koncepcję urbanologii. Przedstawił ją m.in. podczas głośnej międzynarodowej wystawy Terra-2 we wrocławskim Muzeum Architektury, w 1981 r.
} 
transportowe, fizjograficzne ${ }^{3}$. Lose nie tylko domaga się, aby refleksja o środowisku zurbanizowanym była zorientowana na człowieka, ale też, by - w drugą stronę - refleksja o człowieku uwzględniała jego wymiar przestrzenny. Tak pomyślana urbanologia prowadzi Losego do pochwały średniowiecznego modelu miasta — i jego zorientowanej bardziej na wolność i kreatywność nowożytnej kontynuacji. Ku urbanologii jest pełne odwołań do tamtych czasów. W tym zwłaszcza do integrującej kulturowo roli chrześcijaństwa. „W zakresie sprawności urbanicznej nigdy nie zbliżyliśmy się do tamtego [tj. średniowiecznego - Ł.M.] poziomu, nawet nie potrafimy tego mentalnie pojąć" - uważa Lose ${ }^{4}$. To właśnie średniowieczu i „czasom późniejszym” udało się „uzyskać sprawność urbanizacyjną przy zachowaniu niezbędnej, dialektycznej równowagi między tym, co dzieli, a tym, co łączy; między tym, co funkcjonalne, a tym, co nadfunkcjonalne [czyli, w terminologii Losego, między pracą a kulturą — Ł.M.]; między tym, co energetyczne, a tym, co informacyjne”. Osiągnięcia tamtych minionych epok „ciągle lśnią pośród europejskich dzieł urbanistyki, architektury, myśli i organizacji oraz ekonomii - ciągle korzystamy z tamtego dorobku, ciągle fascynują tamte miasta, ich rynki, budowle prywatne, publiczne, ratusze i katedry"s. Średniowieczne miasta dbały o zachowanie odpowiedniej, optymalnej liczby. Zauważmy, że miały one po kilkanaście-kilkadziesiąt tysięcy mieszkańców — np. ludność Wrocławia zwiększyła się w latach $1327-1526$ z 12 tys. do 22 tys. osób ${ }^{6}$. Sam Lose wskazuje, że „w europejskim kręgu kulturowym już jednostka osadnicza o wielkości około 500 dorosłych mieszkańców może stanowić sprawne ekonomicznie ogniwo urbaniczne"

Autor Ku urbanologii zachwyca się średniowieczną wielopodmiotową strukturą społeczną i instytucjonalną. Była ona „zawsze elastyczna i dostosowana do złożoności podejmowanych zadań". Tylko Europa wykształciła taką wielopiętrową strukturę systemów integracyjnych: ,gdy systemy niższego rzędu okazują się niesprawne, wtedy przywoływany jest system wyższego rzędu, i odwrotnie"8.

Dziedzictwem średniowiecza jest również charakterystyczna sylweta miasta — „wieże kościołów i ratuszy oraz place”. To wizualny urbanistyczny wyraz sfery sacrum, która dominuje nad profanum ${ }^{9}$. Dziś wyrazem podobnej tendencji jest bazylika w Licheniu, której Lose żarliwie broni: Licheń „ukazuje nieodkryty potencjał tego, co społeczne, co zaniedbane, co zagubione, co zapomniane. Powinien być wyrzutem sumienia tzw. elit i rządzących. One jednak komentują

${ }^{3}$ S. Lose, Ku urbanologii. Didaskalia architektury i urbanistyki, Wrocław 2015, s. 24-25.

${ }^{4}$ Ibidem, s. 267.

${ }^{5}$ Ibidem, s. 266.

${ }^{6}$ N. Davies, R. Moorhouse, Mikrokosmos. Portret miasta środkowoeuropejskiego. Vratislavia, Breslau, Wrocław, Kraków 2007, s. 144.

${ }^{7}$ S. Lose, op. cit., s. 412.

8 Ibidem, s. 170-171.

${ }^{9}$ Ibidem, s. 226, por. też rysunki na s. 225. 
Licheń jako zjawisko nielicujące $\mathrm{z}$ ich pojęciem formy i estetyki" ${ }^{10}$ (kolejnym podobnym przykładem jest figura Chrystusa w Świebodzinie). Za najwybitniejszego polskiego architekta Lose uważa Stanisława Niemczyka, projektanta m.in. kościołów nawiązujących formą do stylów historycznych — pisze o nim, że to „chyba największy [twórca] w całej historii polskiej architektury" ${ }^{11}$. Zachwyca się takimi elementami charakterystycznymi dla miast tradycyjnych, jak „niewielka szerokość ulicy i nieregularność jej zabudowy pod względem formy”, „szczyty gotyckich czy barokowych kamienic”, a nawet „cienie na elewacjach” — „renesansowo-barokowe odkrycie”, które „tworzy istotny zespół gradientów w tle sensorycznym ulicy"12. Dziedzictwem chrześcijaństwa jest podział na parafie jako zasada kształtująca strukturę terytorialną. Lose uznaje ją za element kanonu polskiej tożsamości. Postuluje, by tę właśnie strukturę potraktować jako fundament funkcjonalnego rozwoju przestrzeni miejskiej ${ }^{13}$. Dziś jednak nasza urbaniczna rzeczywistość przeżywa kryzys. Zdaniem Losego miasta rozwijają się już co najwyżej ilościowo. Nie są twórcze ${ }^{14}$. Lose odrzuca współczesny dyktat ekonomii i globalizację. Wskazuje, że „pierwszym frontem walki” przeciwko niej są „lokalna kultura, a w niej język i religia” 15 . Apeluje o „przywrócenie człowiekowi konstytuujących go korzeni społeczno-terytorialnych" ${ }^{16}$. Opowiada się za powiązaniem wolności indywidualnej ze wspólnotowością oraz za porzuceniem modelu rodziny nuklearnej i powrotem do modelu rodziny wielopokoleniowej, wraz ze stosownymi zmianami w budownictwie mieszkalnym.

Na pierwszy rzut oka tradycjonalizm Losego może wydać się antymodernistyczny. Wszak — jak przekonuje ten autor - modernizm w urbanistyce i architekturze skupił się na „,zieleni, świeżym powietrzu i transporcie”, zaniedbując silny związek człowieka z miejscem ${ }^{17}$, stworzył przestrzeń pozbawioną ,„punktów orientacyjnych"18 i budował blokowiska („osiedla te z punktu widzenia sztuki urbanistycznej były najczęściej wielką pomyłką", choć Lose przyznaje, że tworzyły własne, ciekawe, odrębne sieci społeczne ${ }^{19}$ ). Niemniej, Stanisław Lose nie tylko był jednym z architektów, którzy na początku lat 90 . z entuzjazmem przywracali pamięć o wrocławskim modernizmie, ale też sam dziś zastrzega, że choć nie akceptuje modernistycznego „widzenia społeczeństwa miasta”, to jednak „nie wyobraża sobie architektury bez idei i praktyki modernizmu”. Jego zdaniem no-

\footnotetext{
10 Ibidem, s. 22, por. też s. 29.

11 Ibidem, s. 47.

12 Ibidem, s. 210.

13 Ibidem, s. 417-418.

14 Ibidem, s. 23.

15 Ibidem, s. 388-389.

16 Ibidem, s. 301.

17 Ibidem, s. 285.

18 Ibidem, s. 210.

19 Ibidem, s. 243.
} 
woczesność jest niespójna, brakuje jej „idei przewodniej”20. Propozycję Losego należałoby więc uznać za taką próbę fuzji tradycjonalizmu z modernizmem, w której ten drugi zyskuje nową, nawiązującą do tradycji ideę przewodnią. Tym bardziej warto potraktować Ku urbanologii jako pretekst do przyjrzenia się neomediewalizmowi i tradycjonalistycznej urbanistyce, a także do zastanowienia się nad możliwymi konsekwencjami wdrażania tych nurtów w architekturę współczesnych miast.

\section{Tradycyjne miasto europejskie — forma i treść}

Długie i bogate są dzieje rozmaitych idealizacji miasta średniowiecznego zachwycających się jego pięknem, skalą czy ustrojem społecznym, politycznym, ekonomicznym. Ich owocem są liczne, współczesne, urbanistyczne modele miast (lub osiedli) programowo małych, wypełnionych architekturą nawiązującą do stylów tradycyjnych, stawiających na ekologię, a nawet próbujących zbliżyć się do ideału ekonomicznej samowystarczalności.

Nie jest łatwo uporządkować taki materiał. Powód jest oczywisty: miasto jako takie jest zjawiskiem złożonym, wielodziedzinowym. Już choćby odpowiedź na pytanie „,czym jest miasto?” okazuje się trudna ${ }^{21}$. Izabela Mironowicz analizuje pojęcie struktury miasta i wskazuje, że składa się ona $\mathrm{z}$ dwóch elementów: a) „struktury funkcjonalno-przestrzennej” (która z kolei zawiera „ułożenie poszczególnych części miasta względem siebie” oraz „sieci, które umożliwiają kontakty pomiędzy poszczególnymi owymi częściami”); b) „układu przestrzennego, który możemy także nazwać fizjonomią czy kompozycją przestrzenną miasta, czyli fizyczny wygląd miasta kształtujący pewien charakterystyczny, odrębny krajobraz" ${ }^{22}$. Ja swoją poniższą wędrówkę śladem idei tradycjonalistycznych też podzieliłem na dwie części, acz inne, niż wynikałoby to ze schematu Mironowicz. W pierwszej skupiam się na formie, a w drugiej na treści miasta. W for m i e mieści się wszystko to, co składa się na ,strukturę miasta” w rozumieniu Mironowicz, a więc oba wskazane przez tę autorkę elementy owego pojęcia (choć wyraźnie przeważa drugi: „kompozycja przestrzenna”). W tre śc i zaś umieściłem wartości, interesy i instytucje, które kształtują życie mieszkańców miasta (tu wyraźnie przeważają wartości). Tak zakreślony zbiór „treści” współgra z niektórymi przytoczonymi przez Mironowicz definicjami miasta — mam na myśli zwłaszcza te autorstwa Arystotelesa (miasto jest wspólnotą, która ,powstaje dla osiągnięcia ja-

${ }^{20}$ Cytaty pochodzą z mojej korespondencji ze Stanisławem Losem.

${ }^{21}$ I. Mironowicz, Miasto, jego struktura i kompozycja - definicje, schematy, relacje przestrzenne, [w:] Wybrane teorie wspótczesnej urbanistyki, red. P. Lorens, I. Mironowicz, Gdańsk 2013, s. $94-102$.

22 Ibidem, s. 102-103. 
kiegoś dobra”, ,istnieje, aby życie było dobre”), Roberta E. Parka („miasto to stan duszy, zbiór obyczajów i tradycji, zachowań i odczuć wytworzonych wokół tych obyczajów i przekazywanych za pomocą tych tradycji") oraz Tadeusza Zipsera (który definiuje miasto za pomocą kategorii potrzeb oraz urządzeń i instytucji służących do ich zaspokajania) ${ }^{23}$. Ten podział na formę i treść należy — rzecz jasna - traktować jako umowny. Obie te sfery przenikają się: konkretna forma miasta bywa uzasadniana jakąśs treścią, np. jakimiś wartościami - i może zwrotnie wpływać na sferę treści, choćby tworząc nowe wartości lub instytucje, które następnie kierują się własnymi interesami i tą drogą wpływają na funkcjonowanie miasta.

\subsection{Forma}

W tej dziedzinie przeciwstawiam sobie nawzajem dwa duże, skonfliktowane, urbanistyczne nurty, które zmagają się z sobą od niemal stu lat: modernizm (za jego punkty kulminacyjne uznaję Le Corbusiera, CIAM, Kartę Ateńską) i tradycjonalizm (który mieści w sobie mniej lub bardziej dosłowne nawiązania do architektury i urbanistyki stylów historycznych, w tym także do tzw. budownictwa wernakularnego, lokalnego). W tym schemacie przypadkiem szczególnym tradycjonalizmu staje się neomediewalizm, czyli idea czerpania ze wzorców średniowiecznych. Ta terminologiczna propozycja jest oczywiście mocno uproszczona i ma charakter roboczy. Oba bieguny opozycji - modernizm i tradycjonalizm należy traktować raczej jako Weberowskie „typy idealne”, a może nawet samą tę opozycję należy uznać za taki właśnie „typ idealny” współczesnego urbanistycznego sporu. Różne szczegółowe koncepcje i realizacje mogą mieścić się bliżej jednego lub drugiego bieguna. Umiejscowienie innych może w ogóle okazać się problematyczne (no bo gdzie np. wstawić ekspresjonizm?). Jednakże zaletą schematu modernizm versus tradycjonalizm jest nie tylko prostota, ale i fakt, że jest on chętnie stosowany (choć nie zawsze z użyciem dokładnie tych dwóch terminów) w celach autoidentyfikacyjnych i polemicznych przez czołowych ideologów obu nurtów ${ }^{24}$.

Klasykiem urbanistycznego tradycjonalizmu jest dziewiętnastowieczny austriacki architekt Camillo Sitte. W 1889 r. opublikował niewielką, ale niezwykle wpływową książkę o planowaniu miast zgodnie z zasadami artystycznymi ${ }^{25}$. Sitte

23 Ibidem, s. 94-102.

24 Por. Le Corbusier, Urbanistyka, Warszawa 2015, s. 41-42, 189-201; L. Krier, Architektura wspólnoty, Gdańsk 2011, s. 5-9, 57-91.

${ }^{25}$ C. Sitte, City Planning According to Artistic Principles, [w:] Camillo Sitte. The Birth of Modern City Planning, red. G.R. Collins, C.C. Collins, New York 2006; bodaj najważniejszym omówieniem poglądów Sittego, kontekstu ich formułowania i ich wpływu jest: G.R. Collins, C.C. Collins, Camillo Sitte. The Birth of Modern City Planning, New York 2006; zob. też E. Barucka, W szkatułach zieleni. Europejski ruch miast-ogrodów 1903-1930, Warszawa 2014, s. 56-57. 
zaleca w niej, by sztuki tej uczyć się od „natury i starych mistrzów”26. Za Arystotelesem uważa, że miasto powinno być tak zaprojektowane, by jego mieszkańcy czuli się bezpieczni i szczęśliwi. To zaś oznacza, że planowanie nie jest jedynie wyzwaniem technicznym, ale powinno być również „w najprawdziwszym i najwyższym sensie przedsięwzięciem artystycznym"27. Do dziś w literaturze przedmiotu można spotkać się z poglądem, że Sitte był po prostu piewcą średniowiecznego miasta ${ }^{28}$ - moglibyśmy więc uznać go za neomediewalistę. Nie jest to do końca ścisłe. Sam Sitte już we wprowadzeniu do swojej książki zaznaczał, że proponowane przez niego zasady stosowane były „w starożytności, w średniowieczu i w renesansie", analizowanym zaś przez niego materiałem są ,głównie plany miast i pozycjonowanie pomników w renesansie i baroku, gdyż te właśnie okresy są nam najbliższe w czasie i przestrzeni" ${ }^{29}$. Został nawet odczytany przez jednego z komentatorów z lat 20. jako po prostu piewca renesansu i baroku ${ }^{30}$. Collinsowie przekonują, że podejście Sittego to bardziej metoda niż pochwała konkretnego stylu, a nazywanie jego koncepcji średniowieczną, barokową czy romantyczną ,jest absurdem"31. Rzecz jednak w tym, że Sitte miał grono bardziej radykalnie nastawionych uczniów i wyznawców, których interesował głównie model średniowieczny, można więc ich uznać za neomediewalistów. Jeden z nich — szwajcarski architekt i archeolog Camille Martin — przetłumaczył dzieło Sittego na francuski. Zrobił to jednak twórczo - istotnie przeredagowując książkę, a nawet dopisując (!) jeden rozdział, w którym chwali (oczywiście pod nazwiskiem Sittego, a nie swoim) średniowieczny model krętej uliczki ${ }^{32}$. Najwyraźniej do tej, wydanej po raz pierwszy w 1902 r., wersji dzieła odniósł się następnie w połowie lat 20. XX w. Le Corbusier w swoim szaleńczym ataku na Sittego, neomediewalizm i w ogóle średniowiecze ${ }^{33}$. To właśnie tam i w tym kontekście znajdujemy słynne Corbusierowskie stwierdzenia typu: „Krzywa ulica to ścieżka dla osłów, prosta ulica to droga dla ludzi” ${ }^{34}$, „Człowiek chodzi prosto, ponieważ ma jakiś cel [...]. Osioł chadza zygzakiem, wałęsa się roztargniony, zupełnie bez głowy”35 itp. Owe „ośle ścieżki” to oczywiście średniowieczne ulice, które miał

26 C. Sitte, op. cit., s. 139.

27 Ibidem, s. 141-142.

28 P. Hall, Cities of Tomorrow. An Intellectual History of Urban Planning and Design in the Twentieth Century, Oxford 2002, s. 104; E. Szpakowska, Architektura miasta idealnego. Wprowadzenie, „Przestrzeń i Forma” 16, 2011.

${ }^{29}$ C. Sitte, op. cit., s. 142.

${ }^{30}$ G.R. Collins, C.C. Collins, op. cit., s. 124-125.

31 Ibidem, s. 64-65.

32 C. Sitte, op. cit., s. 198-205; tę zaskakującą historię szczegółowo opowiadają i analizują G.R. Collins, C.C. Collins, op. cit., s. 78-86.

${ }^{33}$ Le Corbusier, op. cit., s. 37-69, w tym wprost o Sittem: s. 28, 41-42; zob. też G.R. Collins, C.C. Collins, op. cit., s. 116.

${ }^{34}$ Le Corbusier, op. cit., s. 42.

35 Ibidem, s. 37. 
wychwalać Sitte i które należy odrzucić w imię nowoczesności. W ten sposób Sitte, Martin i Le Corbusier dopisali kolejny rozdział do popularnego pod koniec XIX w. w niemieckiej i austriackiej urbanistyce konfliktu między zwolennikami ulic prostych i rzecznikami ulic krzywych (krumme oder gerade Strassen ${ }^{36}$ ), który jest prostym, efektownym, działającym na wyobraźnię przejawem sporu architektury organicznej z klasycystyczną (i modernistyczną). Oczywiście Le Corbusierowi nie chodzi tylko o proste ulice - w tej samej Urbanistyce kreśli wizję miasta dla trzech milionów mieszkańców, w którym najbardziej charakterystycznymi budynkami są zatopione w zieleni, wolno stojące wieżowce ${ }^{37}$. Całkiem na marginesie dodajmy, że przypisywanie średniowiecznemu miastu charakteru wyłącznie organicznego oraz „krzywych ścieżek” nie jest ścisłe, ponieważ ówczesne miasta lokacyjne (a więc od około XII/XIII w. wzwyż) budowane były wedle planu szachownicowego, czyli na sieci prostych, krzyżujących się prostopadle ulic (przykładem jest wrocławskie Stare Miasto). Model organiczny właściwy jest miastom wcześniejszym, przedlokacyjnym (we Wrocławiu widać go na Ostrowie Tumskim).

Sitte nie był pionierem urbanistycznego tradycjonalizmu. Sam zresztą skromnie zaznaczał — w przedmowie do trzeciego wydania swojej książki (1900 r.), że sformułowane przezeń poglądy po prostu „wisiały w powietrzu”, stąd popularność jego dzieła ${ }^{38}$. Łatwo je skojarzyć z wylansowaną jeszcze przez romantyzm fascynacją średniowieczem, a zwłaszcza gotykiem, której charakterystycznymi dziewiętnastowiecznymi przejawami będą choćby neogotyk w architekturze, ruch Arts and Crafts w rzemiośle i sztukach wizualnych czy (przynajmniej niektóre) idee konserwatywne kontestujące nowoczesny, pooświeceniowy i porewolucyjny ład (czy też bezład — jak zapewne woleliby sami konserwatyści) społeczny, polityczny, kulturowy. Collins i Collins wyliczają przykłady znacznie wcześniejszych niż książka Sittego pochwał tradycyjnego modelu miasta (a nawet krzywych uliczek): u Johanna Petera Willebranda (1775), Wilhelma Heinricha Riehla (1854), Samuela Hugginsa (1858) czy w listach marszałka Helmutha von Moltkego z Paryża z $1871 \mathrm{r}^{39}$ Idea nawiązywania do modelu miasta organicznego ma genealogię jeszcze dłuższą, bo sięgającą XVII w., a zaprojektowane w $1868 \mathrm{r}$. przez Fredericka Lawa Olmsteda przedmieście Riverside w amerykańskim stanie Illinois to już w zasadzie miasto-ogród, wyprzedzające o kilkadziesiąt lat propozycje Ebenezera Howarda i Raymonda Unwina, o których piszę nieco dalej ${ }^{40}$. Istotniejszy jest jednak wpływ, jaki wywarł sam Sitte. Jego dziełem zachwycił się — acz z zastrzeżeniami — Josef Stübben, jeden z najważniejszych teoretyków

${ }^{36}$ Zob. G.R. Collins, C.C. Collins, op. cit., s. 40-41, 345-346.

${ }^{37}$ Le Corbusier, op. cit., s. 189-201.

${ }^{38}$ C. Sitte, op. cit., s. 139.

${ }^{39}$ G.R. Collins, C.C. Collins, op. cit., s. 346-347.

${ }^{40}$ Z. Paszkowski, Miasto idealne w perspektywie europejskiej i jego zwiazki z urbanistyka współczesna, Kraków 2011, s. 203-206. 
urbanistyki przełomu XIX i XX w. ${ }^{41}$ Zwolennikami i kontynuatorami Sittego byli tacy urbaniści, jak neomediewalista Karl Henrici oraz Theodor Fischer — jeden z twórców stuttgarckiej szkoły architektury ${ }^{42}$, której tradycjonalizm okazał się tak silny w czasach III Rzeszy, że na jego nadmierny wpływ narzekał sam Albert Speer, główny urbanista Hitlera, ideolog i praktyk totalitarnego neoklasycyzmu ${ }^{43}$.

Do nurtu tradycyjnego należy zaliczyć rozwijany równolegle w Wielkiej Brytanii (a potem w całej Europie) ruch miast-ogrodów. Mówiąc najkrócej, „miasto ogród miało połączyć w sobie korzyści płynące z życia w mieście z walorami, jakie oferuje życie na wsi, chroniąc jednocześnie swoich mieszkańców przed wszelkimi niedogodnościami i utrudnieniami, jakie każdy z tych wyborów niesie"44. Zaproponowany w 1898 r. przez Ebenezera Howarda model zakładał, że miasta-ogrody będą miały ograniczoną powierzchnię (2,4 tys. ha) i liczbę mieszkańców (ok. 30 tys.); „,miały być budowane na terenach wiejskich i otoczone pierścieniem zieleni. Znaczącymi wyróżnikami miasta-ogrodu były kwestie zdrowia i własności spółdzielczej, bogaty program społeczny i kulturalny oraz wykorzystanie na rzecz środowiska dobrodziejstw wynikających z zastosowania energii elektrycznej" "45. Jak pisze Edyta Barucka, ruch wywodził się wprost z brytyjskiej tradycji ogrodowej i tamtejszego wyczulenia na ,piękno naturalnego krajobrazu i otwartej przestrzeni”. Dla organizacji zajmujących się ich ochroną ,podobnie jak dla inicjatorów i propagatorów ruchu miast-ogrodów” inspiracją były „pisma i poglądy Johna Ruskina oraz Williama Morrisa, dla których industrializacja oznaczała niszczenie głębszych ludzkich wartości, powiązanych z otoczeniem oraz sposobem życia i pracy" ${ }^{46}$. Dodajmy, że i Ruskin, i Morris byli zafascynowani średniowieczem.

Te rozmaite brytyjskie, austriackie i niemieckie tradycjonalizmy były dla siebie wzajemną inspiracją. Drugi obok Howarda klasyk idei miasta-ogrodu — Raymond Unwin — powołuje się na Sittego i neomediewalną urbanistykę niemiecką w swojej klasycznej Town Planning in Practice z 1909 r. ${ }^{47}$ Collinsowie wręcz sugerują, że ta książka jest po prostu kontynuacją dzieła Sittego ${ }^{48}$. Ruch miast-

41 G.R. Collins, C.C. Collins, op. cit., s. 97-99.

42 Ibidem, s. 91-92.

43 T. Harlander, Urbanism and Housing Policy in Nazi Germany: A Commentary, [w:] Urbanism and Dictatorship: A European Perspective, red. H. Bodenschatz, P. Sassi, M.W. Guerra, Basel 2015.

44 E. Barucka, op. cit., s. 13.

45 Ibidem.

46 Ibidem, s. 15.

47 Zob. np. R. Unwin, Town Planning in Practice. An Introduction to the Art of Designing Cities and Suburbs, London 1909, s. 97-112; także P. Hall, op. cit., s. 104; por. też E. Barucka, op. cit., s. 60 .

48 G.R. Collins, C.C. Collins, op. cit., s. 363. 
-ogrodów świetnie przyjął się w Niemczech ${ }^{49}$. Uczniem zarówno Unwina, jak i Theodora Fischera był Ernst May ${ }^{50}$ — autor przedstawionej w 1921 r., inspirowanej miastem-ogrodem, koncepcji otoczenia Wrocławia pierścieniem nowych osiedli-satelitów. Możliwości jej realizacji konsultował zresztą bezpośrednio z Unwinem ${ }^{51}$.

Wyraźne wpływy Sittego i koncepcji miasta-ogrodu (wraz z bezpośrednimi cytowaniami) znajdziemy w Budowie miast Romana Felińskiego z 1916 r. ${ }^{52}$ — „pierwszej polskiej książce poświęconej historii budowy miast"53. Autor ostro krytykuje dziewiętnastowieczne budownictwo czynszowe i zaleca m.in. uwzględnienie artystycznego wymiaru przestrzeni miejskiej oraz stawianie „małych niskich domków" jako optymalnego modelu zabudowy mieszkalnej ${ }^{54}$. Jednocześnie jednak opowiada się za sprzyjającymi komunikacji prostymi ulicami, sceptycznie wypowiadając się o „nienaturalnych krzywiznach [...] w myśl wymagań malowniczości szkoły niemieckiej”" ${ }^{55}$. Kilka lat później — w 1923 r. Feliński znajdzie się w gronie współzałożycieli Towarzystwa Urbanistów Polskich i przez dwa lata będzie pierwszym w dziejach prezesem tej organizacji. Po II wojnie światowej będzie tworzył od podstaw polską urbanistykę we Wrocławiu i na Dolnym Śląsku ${ }^{56}$.

Od lat 30. w światowej urbanistyce dominuje nurt przeciwny tradycjonalizmowi, czyli modernizm. CIAM - na czele z Le Corbusierem - otwarcie potępił model miasta-ogrodu na swoim trzecim kongresie w 1930 r. ${ }^{57}$ Trudno nie oprzeć się wrażeniu, że na pozycję zarówno tradycjonalizmu, jak i modernizmu oraz ich wzajemne relacje coraz większy wpływ miały wielka polityka i wielkie konflikty ideologiczne. Modernizm wypracowywał sobie markę ,oficjalnego stylu wolności i demokracji”"58 i ,postępowej myśli planistycznej”" ${ }^{\circ 9}$. Cieniem na tradycjonalizmie położyła się jego ogromna rola w urbanistyce i architekturze III Rzeszy.

49 T. Harris, The German Garden City Movement: Architecture, Politics, and Urban Transformation, 1902-1931, New York 2012; E. Barucka, op. cit., s. 68-83, 170-179; P. Hall, op. cit., s. $119-127$.

${ }^{50}$ E. Herrel, ,, Nieustanne dojrzewanie”- - lata studiów, wille we Frankfurcie i groby poległych na froncie, [w:] Ernst May 1886-1970, red. C. Quiring et al., Wrocław 2012.

51 B. Störtkuhl, Ernst May i Schlesische Heimstätte, [w:] Ernst May 1886-1970, s. 195-198.

52 R. Feliński, Budowa miast. Z ilustracyami i planami miast, Lwów 1916.

53 J. Lewicki, Roman Feliński — architekt i urbanista. Pionier nowoczesnej architektury, Warszawa 2007, s. 144.

${ }^{54}$ R. Feliński, op. cit., s. 38.

55 Ibidem, s. 26.

${ }^{56}$ Feliński zmarł we Wrocławiu, w 1953 r. Pochowany jest na cmentarzu przy ul. Bujwida.

${ }^{57}$ E. Barucka, op. cit., s. 167-168.

${ }^{58}$ P. Lorens, Wspótczesne trendy zmian $w$ strukturze i funkcjonowaniu miast, [w:] Wybrane teorie wspótczesnej urbanistyki, red. P. Lorens, I. Mironowicz, Gdańsk 2013, s. 16.

${ }^{59}$ E. Barucka, op. cit., s. 167. 
Mimo tego typu przeciwności tradycjonalistyczna linia przekazu w urbanistyce nie zniknęła pod naporem modernistycznej ofensywy ${ }^{60}$.

Na przełomie lat 80. i 90. otwartą pochwałę miasta średniowiecznego — a ściślej — „średniowiecznego, włoskiego miasteczka na wzgórzach” (,medieval Italian hilltown") - wygłosili Ernest J. Yanarella i Richard S. Levine z Uniwersytetu Kentucky na podparcie swojej wizji miasta zrównoważonego (sustainable city). Przeciwstawiali organiczną formę takiego włoskiego miasteczka efektom racjonalnego planowania późniejszych okresów historycznych i wskazywali na jej związek ze „społeczną i polityczną heterogenicznością, w której jedyna podzielana przez wszystkie rywalizujące strony (contestants) zasada głosiła, że żaden podmiot - czy to szlachta, czy Kościół, czy gildia albo klasa — nie powinien osiągnąc hegemonicznej, organizującej władzy nad całym miastem”. Przykładami innych pozytywnych cech takiego miasta są „ludzka skala” architektury, „estetyczne bogactwo" i równowaga między obszarem miejskim a wsią ${ }^{61}$. Za znakomity przykład takiego miasta - w dodatku wciąż funkcjonującego - uchodzi Siena ${ }^{62}$.

W ostatnich latach najbardziej znaną szkołą propagującą tradycjonalizm jest Nowy Urbanizm (New Urbanism). Za jego symboliczny początek można uznać powołanie w 1980 r. biura architektonicznego DPZ przez małżeństwo Andresa Duany'ego i Elizabeth Plater-Zyberk, polskiej arystokratki (której stryj Zygmunt Plater-Zyberk był w okresie międzywojennym znanym architektem modernistą w Warszawie). To właśnie ta firma rozpropagowała New Urbanism nie tylko w teorii, ale przede wszystkim w praktyce, przez liczne projekty realizowane w USA. Przedstawiciele tej szkoły

uważają za nieprawdziwy pogląd głoszący, iż klasyczne miasta w ich różnorodności są niemożliwe do kopiowania z uwagi na organiczny charakter ich rozwoju. Uważają oni natomiast, że określony, pożądany obraz heterogenicznej przestrzeni miejskiej można osiągnąć przez szczegółowy projekt, schodzący do różnorodnego detalu. [...] [Nowy Urbanizm] nie oznacza tylko romantycznej nostalgii za dawnym krajobrazem miasta, wiąże się z określonymi, promowanymi przez jego zwolenników zasadami budowy miast i — jednocześnie — organizacji

${ }^{60}$ Collins i Collins rekonstruują następstwo kolejnych koncepcji formułowanych w duchu Sittego w XX w. To m.in. książki The Picturesque Christophera Husseya i The Gothic Revival Kennetha Clarka (lata 1927-1928); The City Eliela Saarinena (1943); ruch British Townscape (lata 40-60.), następnie jego ewolucja w stronę tematyki społecznej (lata 60. — m.in. Kevin Lynch i Jane Jacobs); kontekstualizm (od lat 60.), do którego Collinsowie zaliczają m.in. Roba Kriera (a więc jednego z czołowych ideologów tradycjonalistycznego tzw. Nowego Urbanizmu, starszego brata cytowanego Leona Kriera); prowadzone głównie w latach 70. badania Christophera Alexandra nad tzw. językiem wzorców; wreszcie postmodernizm (od lat 70.), zob. G.R. Collins, C.C. Collins, op. cit., s. 124-128; 16.

${ }^{61}$ E.J. Yanarella, R.S. Levine, The Sustainable Cities Manifesto: Pretext, Text and Post-Text, „Built Environment” 18(4), The Compact City, s. 301-313, Marcham 1992.

${ }^{62}$ T. Harvey, Siena and Sustainability: City and Country in Tuscany, „Terrain.org. A Journal of the Built + Natural Environments" 20, 2007. 
społeczności lokalnych. Stawiany jest więc znak równości między takimi pojęciami, jak charakter planu urbanistycznego, rodzaj architektury, rodzaj społeczności lokalnej ją zamieszkującej ${ }^{63}$.

Nowy Urbanizm „bywa nazywany »planowaniem neotradycyjnym«, co ma uzasadnienie podwójne: zarówno w nawiązaniu do warsztatu planistycznego sprzed prawie stu lat, jak i w promowanych formach architektonicznych. [...] [P]roponuje powrót do wielu typów zabudowy, których stosowanie zaniechane było przez ostatnie dwa pokolenia - a więc do bogatej typologii zabudowy miejskiej z lat 1900-1920", w tym do amerykańskiego neoklasycyzmu, niemieckiego neobaroku oraz do modelu miasta-ogrodu ${ }^{64}$. Najbardziej znanym ideologiem tej szkoły jest wspomniany już Leon Krier $^{65}$, a mecenasem i promotorem - Karol książę Walii, zdeklarowany antymodernista ${ }^{66}$.

Za charakterystyczne dla tradycjonalizmu zjawisko można chyba uznać podział na przeciwników i zwolenników miasta. Zwracają na to uwagę Collins i Collins, gdy piszą, że Camillo Sitte „nie podzielał antymiejskiego punktu widzenia Ruskina i Morrisa, ale raczej akceptował miasto jako żywotny element rozwoju kulturowego"67. Potępienie miasta oraz idealizacja wsi i gór były jednym $\mathrm{z}$ typowych wątków niemieckiego ruchu na rzecz obrony tradycji ojczyźnianych z przełomu XIX i XX w. ${ }^{68} \mathrm{Z}$ drugiej strony — zachwyty nad miastem tradycyjnym, w tym średniowiecznym, są jednak zachwytami nad miastem, a nie wsią. Gdzieś między tymi dwoma sprzecznymi trendami należałoby umieścić koncepcje typu miasto-ogród czy nazistowski Die Neue Stadt Gottfrieda Federa, a więc próby stworzenia mikstury miasta ze wsią, które można też nazwać idealizacjami małych miasteczek czy przedmieść. Konsekwencją tego trendu jest znane i kontrowersyjne zjawisko tzw. suburbanizacji, potępiane od lat 60. przez urbanistów wzywających do ponownego dowartościowania centrów miast i odbudowy tkanki miejskiej (tu klasykiem jest Jane Jacobs). Architektura wspólnoty tradycjonalisty Leona Kriera jest jedną wielką pochwałą miasta ${ }^{69}$ — znajdziemy tam m.in. kąśliwą uwagę pod adresem miasta-ogrodu (,nie jest ani prawdziwym miastem, ani prawdziwym ogrodem"70). Podział na przeciwników i zwolenników miasta nie pokrywa się z podziałem na tradycjonalistów i modernistów, o czym

63 P. Lorens, J. Martyniuk-Pęczek, Od City Beautiful Movement do Nowego Urbanizmu, [w:] Wybrane teorie wspótczesnej urbanistyki, red. P. Lorens, I. Mironowicz, Gdańsk 2013, s. 182-183.

${ }^{64}$ Ibidem, s. 185-186; więcej o Nowym Urbanizmie, a zwłaszcza o jego zasadach — Z. Paszkowski, op. cit., s. 206-211.

65 Por. L. Krier, op. cit.

${ }^{66}$ Przedstawiciele Nowego Urbanizmu współpracują m.in. w ramach międzynarodowej sieci INTBAU (International Network for Traditional Building, Architecture \& Urbanism).

${ }^{67}$ G.R. Collins, C.C. Collins, op. cit., s. 17.

${ }^{68}$ Por. A. Rome-Dzida, Niemieccy artyści w Karkonoszach w latach 1880-1945. Przyczynek do badań nad Heimatkunst, Jelenia Góra 2013, s. 45-58.

${ }^{69}$ Por. L. Krier, op. cit., s. 28-30, 98-115, 132-143, 209-210.

${ }^{70}$ Ibidem, s. 30. 
świadczyć może choćby Le Corbusier, którego wizja miasta dla trzech milionów mieszkańców może - wbrew pierwszemu wrażeniu — zostać odczytana właśnie jako antymiejska, dezurbanizacyjna (w takim duchu interpretuje go Marshall $\left.\operatorname{Berman}^{71}\right)^{72}$.

\subsection{Treść}

Andreas Billert nie przeczy, że średniowieczne miasto jest piękne. Zwraca jednak uwagę, że ta jego zaleta nie była „produktem idealnego "masterplanu”, lecz efektem procesów ekonomicznych: spekulacja gruntami prowadziła do rozdrobnienia parceli, to zaś z kolei do zastąpienia „,użych areałów z wolno stojącą zabudową na rzecz wąskich działek zwarcie zabudowanych domami, usytuowanymi szczytem do ulicy", a więc do modelu, który stał się czymś w rodzaju kanonu piękna tradycyjnego miasta europejskiego. Zachwyt jego wyglądem pojawia się dopiero w późnym średniowieczu. Świadczą o tym ówczesne przedstawienia widoków miast. Ale i one - zdaniem Billerta - miały cel ekonomiczny. Miały promować piękno i bogactwo miast, by ułatwić mieszczaństwu dostęp do kredytów bankowych ${ }^{73}$.

Tak oto zaczynamy przyglądać się średniowiecznemu miastu - i generalnie średniowieczu - pod kątem jego treści, nie zaś form. Chętnie przywoływanym klasykiem takiego myślenia jest słynny niemiecki socjolog Max Weber. Analizując miasta starożytne, średniowieczne i orientalne, wskazywał, że kluczowe dla zdefiniowania miasta jest zestawienie jego funkcji ekonomicznej z polityczno-administracyjną. Dodatkowo na Zachodzie masowo pojawiły się miasta, które były nie tylko rynkami i twierdzami, lecz także ,gminami miejskimi”. O takiej gminie można „mówić tam, gdzie mamy do czynienia z osadami o przynajmniej relatywnie wyraźnie zarysowanym rzemieślniczo-kupieckim charakterze, cechu-

${ }^{71}$ M. Berman, ,W Wsystko, co stałe, rozplywa się w powietrzu”. Rzecz o doświadczeniu nowoczesności, Kraków 2006, s. 215-221.

72 Podobnie można podejść do innego wskazanego przez Collinsów sporu: między planowaniem w wielkiej skali, schematycznym, „często geometrycznym”, a tym w małej skali, wrażliwym na szczegół i walory krajobrazowe. Praktyka pokazuje, że nie są to dwa komplementarne podejścia do planowania, lecz dwa przeciwstawne nurty. „Być może całą historię planowania na Zachodzie da się opisać jako wahanie (fluctuation) pomiędzy tymi dwiema postawami” - zastanawiają się Collinsowie. Sitte oczywiście reprezentuje drugie z tych podejść (G.R. Collins, C.C. Collins, op. cit., s. 121-123). Ale czy da się je utożsamić z tradycjonalizmem? Niekoniecznie. Ten spór przypomina raczej podział na tradycję klasycystyczną (racjonalną, geometryczną, nawiązującą do antyku) i organiczną (gotyk, barok, romantyzm), do którego nota bene wprost odwołuje się Le Corbusier w Urbanistyce, jednoznacznie opowiadając się za klasycyzmem. Z tego punktu widzenia mielibyśmy nie jeden, lecz dwa szerokie nurty, które można by uznać za tradycjonalistyczne (co jednak nie wiązałoby się z uznaniem modernizmu za ,inny tradycjonalizm”).

${ }^{73}$ A. Billert, Miasto europejskie i jego droga do miasta postindustrialnego, [w:] Wybrane teorie wspótczesnej urbanistyki, s. 74-75. 
jącymi się następującymi znamionami: 1) umocnieniami, 2) targiem, 3) własnym sądem i co najmniej po części własnym prawem, 4) związkowym charakterem i towarzyszącą mu 5) przynajmniej częściową autonomią i autokefalicznością, a zatem także administrowaniem przez organy, w których ustanawianiu uczestniczyli w jakiejś mierze mieszczanie jako tacy"74. Nieco dalej Weber zauważa, że „postać najbardziej zbliżoną do czystego typu idealnego” przybrało „miasto średniowiecznego Zachodu, i to szczególnie miasto położone na terytorium rozciągającym się na północ od Alp"75. W tej Weberowskiej definicji nie ma ani słowa o strukturze przestrzennej czy o walorach estetycznych.

Pochwałę średniowiecza znajdziemy u wielu myślicieli, z różnych nurtów ideowych — od francuskiego tradycjonalisty René Guénona po rosyjskiego anarchistę Piotra Kropotkina.

Guénon to jeden z najbardziej radykalnych dwudziestowiecznych zwolenników tezy o upadku świata Zachodu. Jest klasykiem nurtu, który w literaturze nazywany bywa tradycjonalizmem integralnym lub perennializmem, głoszącego, że najgłębszą i fundamentalną warstwą kultury są niezmienne prawdy tradycji (utożsamianej ze sferą sacrum), których przejawem są m.in. sfera symboli oraz religie, zwłaszcza ich ezoteryczne nurty. Tradycjonaliści chętnie przeciwstawiają „uduchowiony” Wschód pogrążonemu w materializmie Zachodowi. Tak też robił Guénon. Do tego stopnia, że opuścił Zachód, przeszedł na islam i osiadł w Kairze. Nie tylko uważał, że Zachód sprzeniewierzył się tradycji, porzucając ją na rzecz materializmu, racjonalizmu, indywidualizmu, pragmatyzmu. Wątpił nawet, czy Zachodowi w ogóle uda się ponownie nawiązać $\mathrm{z}$ nią kontakt (z zastrzeżeniem, że jedyną nadzieję na to daje katolicyzm). Za ostatni $w$ dziejach Zachodu czas wierności tradycji uważał średniowiecze ${ }^{76}$.

Wizję europejskiego miasta średniowiecznego jako oazy wolności i współpracy oraz — w efekcie — rozkwitu sztuk i nauk nakreślił klasyk anarchizmu Piotr Kropotkin w swojej Pomocy wzajemnej jako czynniku rozwoju ${ }^{77}$. Nie tylko przeciwstawił zasadę wolności i pomocy wzajemnej średniowiecznych miast opresyjnym zakusom feudalizmu i Kościoła, ale też przy okazji zachwycił się ówczesną architekturą:

budowle średniowieczne były wielkie, ponieważ zrodziła je wielka idea. Wyrosły one, jak sztuka grecka, z wielkiej idei braterstwa i zjednoczenia, wykuwanej w miastach. [...] Smukła dzwonnica wyrastała nad katedrą, w której tętniło życie całego miasta, a bynajmniej nie była rusztowaniem bezmyślnem, jak np. paryska wieża Eiffla, ani też nie brzydką budowlą jak londyńska Tower Bridge, wstydliwie ukrywająca szkielet żelazny pod powłoką kamienną ${ }^{78}$.

${ }^{74}$ M. Weber, Gospodarka i spoleczeństwo. Zarys socjologii rozumiejącej, Warszawa 2002, s. 917.

${ }^{75}$ Ibidem, s. 923.

76 R. Guénon, The Crisis of the Modern World, Varanasi 2007, s. 37.

77 P. Kropotkin, Pomoc wzajemna jako czynnik rozwoju, Warszawa 1921, s. 124-168.

78 Ibidem, s. 161. 
Ta złota era miast w Europie skończyła się — pisze Kropotkin — wraz z nadejściem absolutyzmu w XV i XVI w. Nota bene „księcia anarchistów” znajdujemy wśród autorów, którzy zainspirowali ideę miasta-ogrodu ${ }^{79}$ — acz kluczowe dla miast-ogrodów okazały się dwa inne jego dzieła: Zdobycie chleba oraz Pola, fabryki $i$ warsztaty (bo „stały się pierwszą artykulacją idei powiązania przemysłu i rolnictwa w samowystarczalnych wspólnotach" ${ }^{80}$ ). Na samym dole, a więc niejako u podstaw słynnego, kluczowego dla miast-ogrodów Howardowskiego diagramu pokazującego ,trzy magnesy” przyciągające ludzi (te magnesy to: miasto, wieś oraz miasto-wieś - ten trzeci magnes jest właśnie na dole i wyraża ideę miasta-ogrodu), odnajdujemy słowa: „,wolność — współpraca”. „To nie retoryka; to samo serce tego planu" - uważa Peter Hall ${ }^{81}$. Nad Howardowską wizją unosi się więc duch Kropotkina. Nawiasem mówiąc, Hall twierdzi wręcz, że to właśnie anarchizm zainspirował pierwsze ważne współczesne koncepcje urbanistyczne - stąd zastosowane przez niego określenie ,anarchistyczne korzenie ruchu planistycznego" 82 .

Admiratorem średniowiecza był brytyjski pisarz G.K. Chesterton, propagator tzw. dystrybutywizmu — inspirowanej katolicyzmem idei, która zakłada m.in. wzmocnienie demokracji poprzez uwłaszczenie przedstawicieli niższych warstw oraz spółdzielczą własność przedsiębiorstw (postulat, by wzmacniać to, co oddolne, zbliża dystrybutywizm do anarchizmu). W portalu polskich dystrybucjonistów można znaleźć taki oto opis poglądów Chestertona:

\begin{abstract}
Postrzegał on średniowiecze jako czasy jedności społeczno-religijnej Europy, w których urzeczywistniały się ideały ludzkiej wolności i samorządu. Średniowiecze pozostawało nieskażone dominacją gospodarczo-polityczną oligarchicznych elit, które to elity pozostawały w wizji myśliciela odpowiedzialne za podkopanie i zniszczenie przedreformacyjnego, chrześcijańskiego porządku Europy ${ }^{83}$.
\end{abstract}

Te rozmaite idealizacje średniowiecznego miasta i średniowiecza ciekawie współgrają z tzw. neomediewalizmem w naukach politycznych. Zgodnie z tym poglądem nasz współczesny świat odchodzi od porządku „westfalskiego”, którego istotą były relacje między państwami narodowymi, suwerennymi na własnych obszarach. Model ten rozrywany jest przez — z jednej strony — globalizację, a jednocześnie - z drugiej strony — przez „fragmentację”, czyli np. rosnące w siłę podmioty lokalne, regionalne czy pozapaństwowe (choćby religijne). Mimo to państwa narodowe wciąż zachowują bardzo istotną pozycję. Efektem

${ }^{79}$ E. Barucka, op. cit., s. 23, 71; P. Hall, op. cit., s. 91-92.

${ }^{80}$ E. Barucka, op. cit., s. 71.

${ }^{81}$ P. Hall, op. cit., s. 95; E. Howard, Miasta-ogrody jutra, Gdańsk 2015, s. 31-35.

82 P. Hall, op. cit., s. 3.

${ }^{83}$ P. Musiewicz, Charles'a Sarole'a i Gilberta Keith Chestertona Listy o sprawach polskich, „Politeja. Pismo Wydziału Studiów Międzynarodowych i Politycznych Uniwersytetu Jagiellońskiego” 12, 2009, cyt. za: K. Sadło, Człowiek, który byt Chestertonem, Kraków 2014, fragment pt. Dystrybutysta za: Dystrybucjonizm.pl — Rodzinne Strony Ekonomii. 
jest nowy, znacznie bardziej złożony model, który przypomina porządek ustrojowy średniowiecznej Europy. Jest to więc - jak pisze Jörg Friedrichs — „system nakładających się na siebie władz i rozproszonych lojalności”. Analogia do średniowiecza sięga jeszcze dalej. Podobnie jak wówczas rywalizowały dwie zasady uniwersalistyczne: Kościół i cesarstwo, tak i teraz mamy do czynienia z podobnym sporem — tyle że dwiema współczesnymi zasadami uniwersalistycznymi są model państwa narodowego i „transnarodowa gospodarka rynkowa” ${ }^{94}$. Grzegorz Lewicki tropi tendencje neomediewalistyczne jeszcze szerzej - bo także m.in. w socjologii, filozofii i ekonomii. Łączy neomediewalizm z modelem interpretacji rzeczywistości za pomocą kategorii sieci, wypracowując w ten sposób pojęcie sieciowego neomediewalizmu. Ta nowośredniowieczna współczesność charakteryzuje się - w jego ujęciu — m.in. decentralizacją władzy, próbami osłabiania „szoku przyszłości” czy „społeczeństwa ryzyka” za pomocą komunitaryzmu i religijności, nowym paternalizmem, „obroną pojęć granicznych w filozofii przez elity w opozycji do postmodernizmu i innych rodzajów sceptycyzmu" czy wreszcie „wzrostem odsetka populacji wychowanej w systemie patriarchalnym" 85 .

\section{Wątpliwości dotyczące tradycyjnego modelu miasta}

Propozycje tradycjonalistów rodzą kilka podstawowych dylematów. Wyliczę je, nie próbując ich rozwiązać.

Po pierwsze - w jakim stopniu dowolny, a w jakim konieczny jest związek formy miasta $\mathrm{z}$ jego treścią? Nad podobnym pytaniem zastanawia się Jörg Friedrichs $w$ odniesieniu do relacji między neomediewalizmem jako wielowarstwowym, rozproszonym modelem organizacji życia zbiorowego a podstawowymi wartościami współczesnego Zachodu, takimi jak demokracja czy prawa człowieka. Jego zdaniem neomediewalizm im nie szkodzi, a może nawet je wzmacnia ${ }^{86}$. Można zaryzykować hipotezę, że na dłuższą metę forma (np. ustrojowa czy architektoniczna/urbanistyczna) nie jest całkiem obojętna dla treści (czyli wartości, interesów, instytucji kształtujących życie mieszkańców danego miejsca) — i vice versa. Acz oczywiście w praktyce te połączenia formy z treścią bywają raczej dowolne, o czym świadczy choćby socrealistyczna zasada „narodowe w formie, socjalistyczne w treści", której przejawem była m.in. pastiszowa odbudowa starówek po II wojnie światowej (klasyczne przykłady Warszawa i Wrocław) — w tym wypadku quasi-średniowieczne, quasi-renesansowe czy quasi-barokowe opakowanie skrywało za fasadami kamienic zwykłe socjalistyczne osiedla zarządzane

${ }^{84}$ J. Friedrichs, The Meaning of New Medievalism, „European Journal of International Relations" 7(4), 2001.

${ }^{85}$ G. Lewicki, Sieciowa teoria nowego średniowiecza, „Pressje” 20, 2010.

86 J. Friedrichs, op. cit. 
przez instytucje totalitarnego państwa. W późniejszym okresie podobnym (choć już nie totalitarnym w treści) nawiązaniem były odbudowy z lat 80. i 90., te kojarzone z postmodernizmem (np. starówka w Kołobrzegu czy północna pierzeja rynku w Kłodzku). Państwa totalitarne i demokratyczne budowały — i budują — w rozmaitych stylach, zarówno historyzujących, jak i współczesnych. Tradycjonalizm i modernizm służyły obu tym typom ustrojów. Ale czy na dłuższą metę — powtórzę pytanie — ta dowolność da się utrzymać? Czy można być szczęśliwym i samowystarczalnym (jak chce Arystoteles) w każdej przestrzeni? Czy samorządność, pomocniczość, solidarność (za katolicką nauką społeczną) dają się z równym powodzeniem realizować w każdym typie przestrzeni? A może jest całkiem odwrotnie: przestrzeń ma drugorzędne znaczenie, a programy „miękkiej rewitalizacji” (aktywizującej mieszkańców trudnych dzielnic) pokazują, że te same cele można osiągać w bardzo różnym otoczeniu?

Po drugie - do czego nawiązuje tradycjonalizm? Czy do historii (i jakichś konkretnych historycznych stylów), czy do lokalnego kontekstu (i jak rozumianego)? Wszak ów kontekst — jak pisze architekt Izabela Gajny — „nie musi wynikać ze stylu. Chodzi nie o style, ale o lokalne formy i materiały — dachówka, mur, otwory, kolor. To po prostu pasuje do danego krajobrazu i stąd jest tradycyjne. Style są wtórne. Zabijają kreatywność"87. Z tej perspektywy „tradycja a historia to dwie różne rzeczy" 88 . Tradycja jest żywą, otwartą na kreatywność, nieprzerwaną kontynuacją tego, co przede wszystkim lokalne. Lokalność zaś to formy, które ,powstają naturalnie w odpowiedzi na warunki klimatyczne, zasobność (w materiały lub potencjał ludzki lub ekonomiczny)"89.

Po trzecie — jeśli jednak tradycjonalizm miałby „nawiązywać do historii”, to co to oznacza? Jak daleko ma sięgać taka kontynuacja — zarówno w formie, jak i w treści? Czy do starych stylów mają nawiązywać jedynie fasady budynków? Czy także ich wnętrza? Czy — jeszcze dalej — ich konstrukcja i zastosowane w budowie materiały? Czy to samo dotyczy np. ustroju miasta? A także roli instytucji religijnych oraz naukowych, artystycznych, rzemieślniczych? I wreszcie: do jakich dokładnie historycznych form i treści chcemy nawiązywać i jakie będą kryteria ich wyboru? Czy lepszy jest klasycyzm, czy gotyk? Zachwalane przez Le Corbusiera klasyczne „proste drogi” czy potępiane przez niego „ośle ścieżki” miasta organicznego?

Po czwarte - nawet jeśli zgodzimy się co do modelu (i w formie, i w treści) europejskiego miasta, to jak go wdrażać w praktyce? Żyjemy w czasach całkowitego rozproszenia w kształcie, użytkowaniu i zarządzaniu przestrzenią miejską. Wynika to z przyczyn ekonomicznych (wolny rynek, rozproszona własność, wielość niezwiązanych z sobą procesów inwestycyjnych), kulturowych (mamy

87 Cytat z prywatnej korespondencji dotyczącej niniejszego tekstu. Izabela Gajny jest związana z siecią INTBAU (International Network for Traditional Building, Architecture \& Urbanism).

${ }^{88}$ Ibidem.

${ }^{89}$ Ibidem. 
do czynienia raczej z wielością małych „przestrzennych opowieści” niż z jakąś nadrzędną wielką narracją), ustrojowych (demokracja, zasada pomocniczości, multi-level governance, a w tym wszystkim rozproszenie administracji i narzędzi planowania przestrzennego). W efekcie „model współczesnego miasta określić można mianem struktury podzielonej, zdefragmentowanej i znacznie mniej czytelnej od jej modernistycznego odpowiednika” ${ }^{90}$. „Dotychczasową jasność celów i zadań rozwoju miejskiego epoki »modernistycznego miasta industrialnego« zastąpiła sytuacja niepewności i zaskoczenia, ograniczająca m.in. skuteczność dotychczasowego systemu planowania" ${ }^{91}$. Współczesne miasta stanęły w obliczu „zagrożenia dezintegracją przestrzeni społeczno-gospodarczej”92. W tym kontekście wizję Stanisława Losego z Ku urbanologii można uznać za przykład próby powrotu do wielkiej narracji, a więc i wyjścia z etapu miasta postmodernistycznego (czy postindustrialnego). W podobnym kierunku idzie Leon Krier, gdy proponuje model „policentrycznego miasta społeczności miejskich”, oczywiście tradycjonalistycznego $\mathrm{w}$ formie ${ }^{93}$. Tyle że próby praktycznego wdrożenia tego typu wizji mogą sprowadzić się do jednej z dwóch tendencji: a) tworzenia nowych miast, w oderwaniu od dotychczasowych; b) gettoizacji w dużych miastach. Czy — i jak — da się zrealizować miasto tradycyjne w formie i w treści (np. w modelu Losego) w ramach funkcjonującej tkanki dużego miasta? I czy punktem dojścia tego typu zabiegów nie będzie po prostu utworzenie dobrze wyglądającego skansenu, który funkcjonowałby jedynie jako atrakcja turystyczna?

Po piąte - słabą stroną tradycjonalizmu wydaje się ekonomia. Nie jest do końca jasne, jaka miałaby być gospodarcza podstawa funkcjonowania takiego miasta. To pytanie jest tym bardziej istotne, że ewentualne zabiegi na rzecz odzyskania/ uzyskania historycznej (względnie tradycyjnej w sensie lokalnym) formy są kosztowne. Długofalowo nie można ich sprowadzić do prostej nadziei na pozyskanie publicznych środków na remonty i inwestycje oraz prowadzenie protekcjonistycznej polityki gospodarczej przez państwo i samorządy na objętych taką interwencją terenach miejskich. Z drugiej strony — można sobie wyobrazić, że samo takie małe miasto działa jak przedsiębiorstwo, żyjąc ze sprzedaży i wynajmu nieruchomości oraz miejsc noclegowych inwestorom i turystom spragnionym piękna, uroku, relatywnej ciszy. To jednak znów jest model skansenu, o którym wspominałem w poprzednim punkcie. Można oczywiście wyobrazić sobie model zaawansowany, w którym miasto żyje z produkcji i sprzedaży wysokiej jakości dóbr i usług, choćby lokalnych, rzemieślniczych. Realizacja takiej wizji wymaga jednak kompleksowego, konsekwentnego, długofalowego podejścia do danego miejsca.

\footnotetext{
${ }^{90}$ P. Lorens, op. cit., s. 27.

91 A. Billert, op. cit., s. 84.

92 Ibidem, s. 88.

${ }^{93}$ L. Krier, op. cit., s. 133-199.
} 
Po szóste - kontrowersyjny może wydawać się postulat monokulturowości takiego miasta, sformułowany wprost przez Losego ${ }^{94}$, czy też pokrewny model względnej ekskluzywności społecznej i kulturowej, która wynika logicznie z chęci utrzymania niewielkiej skali takiego ośrodka. Miasto średniowieczne było właśnie takie - zamknięte za murami, w dodatku silnie zhierarchizowane społecznie i politycznie. Czy taki właśnie trend może pojawić się w Europie jako odpowiedź na m.in. najnowsze fale migracji? I czy takie właśnie społeczne i kulturowe zamykanie Zachodu jest implicite wpisane w neomediewalizm i tradycjonalizm?

\section{Urbanology: Towards a Revival of the Traditional European Town}

\section{Abstract}

"Urbanology" - the term used in the title of the book Towards urbanology by the architect Stanisław Lose from Wrocław - refers to his idea of "a field of knowledge whose main subject is a man in an urbanised world". Therefore urbanology is opposed to urbanistics, which - according to Lose - is more interested in economy, transportation or spatial planning than in people. The author of Towards urbanology strongly appreciates the medieval model of town - and its more freedom-oriented, and creativity-oriented, continuation in later ages. The author is also very impressed by the historical role of christianity as the cultural integrator of urban societies. But Lose's book is only a pretext for briefly describing the contemporary history of the traditionalist current in urbanism and enthusiastic opinions about the Middle Ages expressed by such different authors as René Guénon, Peter Kropotkin or G.K. Chesterton. Nowadays the so-called neomedivalism tries to interpret the current cultural, political and administrative diversity of Europe as a new version of the multi-level and polycentric order associated with the Middle Ages. But neomedievalism and urbanistic traditionalism raise some questions — for example those about the limits of being inspired by the Middle Ages, about the economy of the neomedieval model of town or about the relationship between the notion of the so-called living tradition in urbanism and architecture on the one hand - and historical styles on the other.

Keywords: tradition, traditionalism, New Middle Ages, neomedievalism, new urbanism, urbanology, modernism

\section{Bibliografia}

Barucka E., W szkatułach zieleni. Europejski ruch miast-ogrodów 1903-1930, Warszawa 2014.

Bełch K. ks., Katolicka nauka społeczna. Podręcznik dla studentów teologii i nauk społecznych, Kielce 2007.

Berman M., „Wszystko, co state, rozplywa się w powietrzu”. Rzecz o doświadczeniu nowoczesności, Kraków 2006.

Billert A., Miasto europejskie i jego droga do miasta postindustrialnego, [w:] Wybrane teorie wspótczesnej urbanistyki, red. P. Lorens, I. Mironowicz, Gdańsk 2013.

${ }^{94}$ S. Lose, op. cit., s. 418. 
Collins G.R., Collins Ch.C., Camillo Sitte. The Birth of Modern City Planning, Mineola-New York 2006.

Corbusier Le, Urbanistyka, Warszawa 2015.

Davies N., Moorhouse R., Mikrokosmos. Portret miasta środkowoeuropejskiego. Vratislavia, Breslau, Wrocław, Kraków 2007.

Feder G., Die Neue Stadt. Versuch der Begründung einer neuen Stadtplanungskunstaus der sozialen Struktur der Bevölkerung, Berlin-Heidelberg 1939.

Feliński R., Budowa miast. Z ilustracyami i planami miast, Nakładem Księgarni Gubrynowicza i Syna, Lwów 1916, http://pbc.gda.pl/dlibra/doccontent?id=5434.

Friedrichs J., The Meaning of New Medievalism, „European Journal of International Relations” 7(4), 2001, https://www.researchgate.net/publication/249690919_The_Meaning_of_New_ Medievalism.

Guénon R., The Crisis of the Modern World, Varanasi 2007.

Hall P., Cities of Tomorrow. An Intellectual History of Urban Planning and Design in the Twentieth Century, Oxford 2002.

Harlander T., Urbanism and Housing Policy in Nazi Germany: A Commentary, [w:] Urbanism and Dictatorship: A European Perspective, red. H. Bodenschatz, P. Sassi, M.W. Guerra, Birkhauser Basel 2015, https://books.google.pl/books?id=fe9eCAAAQBAJ\&lpg=PA6\&ots=Q2qQmGzHGN\&dq $=$ tilman $\% 20$ harlander $\% 20$ urbanism $\& \mathrm{hl}=\mathrm{pl} \& \mathrm{pg}=\mathrm{PA} 148 \# \mathrm{v}=$ onepage $\& \mathrm{q}=$ tilman $\% 20$ harland er\%20urbanism\&f=false.

Harris T., The German Garden City Movement: Architecture, Politics, and Urban Transformation, 1902-1931, New York 2012, https://www.google.pl/url?sa=t\&rct=j\&q=\&esrc=s\&source=web $\& c d=6 \&$ cad $=$ rja\&uact $=8 \&$ ved $=0$ ahUKEwjepZfhqIfLAhWIIJoKHeMCD5MQFgg8MAU\&url $=$ https $\% 3 \mathrm{~A} \% 2 \mathrm{~F} \% 2 \mathrm{Facademiccommons}$.columbia.edu $\% 2 \mathrm{Fdownload} \% 2 \mathrm{Ffedora}$ content $\% 2 \mathrm{Fd}$ ownload\%2Fac\%3A144008\%2FCONTENT\%2FHarris_columbia_0054D_10545.pdf\&usg=A FQjCNHgG8xqfkqbHB0A7h41EeRGV4Q2iw.

Harvey T., Siena and Sustainability: City and Country in Tuscany, „Terrain.org. A Journal of the Built + Natural Environments" 20, Summer/Fall 2007, http://www.terrain.org/articles/20/ harvey.htm.

Herrel E., „Nieustanne dojrzewanie” — lata studiów, wille we Frankfurcie i groby poległych na froncie [w:] Ernst May 1886-1970, red. C. Quiring et al., Wrocław 2012.

Howard E., Miasta-ogrody jutra, Warszawa-Gdańsk 2015.

Krier L., Architektura wspólnoty, Gdańsk 2011.

Kropotkin P., Pomoc wzajemna jako czynnik rozwoju, Warszawa 1921, http://rcin.org.pl/dlibra/doc metadata? $\mathrm{id}=32291 \&$ from $=$ publication.

Lewicki G., Sieciowa teoria nowego średniowiecza, „Pressje” 20, 2010, http://pressje.pl/media/ pressje_shop/article/article_10_issue14.pdf.

Lewicki J., Roman Feliński - architekt i urbanista. Pionier nowoczesnej architektury, Warszawa 2007.

Lorens P., Wspótczesne trendy zmian w strukturze i funkcjonowaniu miast, [w:] Wybrane teorie wspótczesnej urbanistyki, red. P. Lorens, I. Mironowicz, Gdańsk 2013.

Lorens P., Martyniuk-Pęczek J., Od City Beautiful Movement do Nowego Urbanizmu, [w:] Wybrane teorie wspótczesnej urbanistyki, Gdańsk 2013.

Lose S., Ku urbanologii. Didaskalia architektury i urbanistyki, Wrocław 2015.

Mironowicz I., Miasto, jego struktura i kompozycja - definicje, schematy, relacje przestrzenne, [w:] Wybrane teorie współczesnej urbanistyki, red. P. Lorens, I. Mironowicz, Gdańsk 2013.

Musiewicz P., Charles'a Sarole'a i Gilberta Keith Chestertona Listy o sprawach polskich, „Politeja. Pismo Wydziału Studiów Międzynarodowych i Politycznych Uniwersytetu Jagiellońskiego" 12, 2009. 
Paszkowski Z., Miasto idealne w perspektywie europejskiej i jego związki z urbanistyką wspótczesna, Kraków 2011.

Quiring C. et al., Ernst May 1886-1970, Wrocław 2012.

Rome-Dzida A., Niemieccy artyści w Karkonoszach w latach 1880-1945. Przyczynek do badań nad Heimatkunst, Jelenia Góra 2013.

Sadło K., Człowiek, który byt Chestertonem, Kraków 2014, http://www.dystrybucjonizm.pl/ krzysztof-sadlo-g-k-chesterton-dystrybutysta/.

Sitte C., City Planning According to Artistic Principles, [w:] G.R. Collins; Ch.C. Collins, Camillo Sitte. The Birth of Modern City Planning, New York 2006.

Störtkuhl B., Ernst May i Schlesische Heimstätte, [w:] Ernst May 1886-1970, Wrocław 2012.

Szpakowska E., Architektura miasta idealnego. Wprowadzenie, „Przestrzeń i Forma” 16, 2011, http://www.pif.zut.edu.pl/pif-16_pdf/A-04_Szpakowska.pdf.

Unwin R., Town Planning in Practice. An Introduction to the Art of Designing Cities and Suburbs, T. Fisher Unwin, London 1909, https://ia902706.us.archive.org/8/items/townplanninginp00 unwigoog/townplanninginp00unwigoog.pdf.

Weber M., Gospodarka i społeczeństwo. Zarys socjologii rozumiejacej, Warszawa 2002.

Wybrane teorie współczesnej urbanistyki, red. P. Lorens, I. Mironowicz, Gdańsk 2013.

Yanarella E.J., Levine R.S., The Sustainable Cities Manifesto: Pretext, Text and Post-Text, „Built Environment" 18(4), The Compact City 1992, pp. 301-313, http://www.jstor.org/stable/23288521. 